\title{
EFFECT OF EMS AND SA ON THE FREQUENCY OF PLANTS CARRYING CHLOROPHYLL DEFICIENT SECTORS IN $M_{1}$ GENERATION OF WINGED BEAN
}

\author{
A.S.Sonavane* \\ Department of Botany, Shardabai Pawar Mahila Mahavidyalaya, Shardanagar, Baramati, Dist. Pune (M.S.) India \\ 413115.
}

*Corresponding Author Email: ajinathsonavane@gmail.com

\begin{abstract}
Objective of the present investigation has been to induce genetic variability in winged bean especially in its quantitative and qualitative characters. This would help in developing improved varieties of winged bean through of mutation breeding. In the present work, the seeds of winged bean of variety (cultivars) II-EC-178313 and 21 38825 were treated with two chemical mutagens like Ethyl Methane Sulfonate (EMS) and Sodium Azide (SA) to induce mutations. From present studies, it is quite clear that the varied concentrations of both the EMS and SA have proved effective in inducing the chlorophyll deficient sectorial types in both the varieties of winged bean. The different kinds of sectors such as yellow (xantha), light green (viridis), yellow green (chlorina) and white (albina) types were observed on leaves.
\end{abstract}

\section{KEY WORDS}

Psophocarpus tetragonolobus (L.) DC, induce genetic variability

\section{INTRODUCTION}

Winged bean botanically described as Psophocarpus tetragonolobus (L.) DC. belongs to family fabaceae. It is also known as Goa bean, four angled bean, four cornered bean, Manila bean, is atropical legume plant native to Papua New Guinea.Winged bean is extensively cultivated in the countries like Myanmar, India, Indonesia, Bangladesh, Srilanka, Cambodia, and Philippines. The systematic and extensive work on taxonomical position of winged bean was carried out by Verdcourt and Halliday (1978). It is a perennial /annual, twining, glabrous, self-pollinating herbaceous plant.The roots are numerous and tuberous, stem is firm and herbaceous, leaves are pinnately trifoliate, petiolate, flower shows the variation in colour like blue, bluish white or purple.

Winged bean has large potential to fulfill the need of staple food that is rich in protein and oil for man and as a fodder for animals. Masefield (1973) was the first person who could highlight the potential utility of this plant. It has been described as wonder legume in the sense that virtually all parts of this plant are edible and immensely nutritious. The winged bean seed rivals the soybean in quantity and quality of its protein. The seeds contain high amount of proteins $(29-42 \%)$ and good quality edible oil (15-20\%), NAS (1975).

Mutagenesis has been widely used as a potent method of enhancing variability for crop improvement, Acharya et. al. (2007). Both the chemical mutagens such as EMS and SA proved to be most effective and powerful mutagens. In plants EMS usually causes point mutations, Okagaki (1991), while SA is marginally mutagenic in different organisms, Arenaz et. al. (1989). Genetic variability is one of the prerequisites for crop improvement. As a consequence, lack of required amount of variability, limits the scope for the selection of better genotypes. Artificially induced mutations are the best way to enlarge genetic variability, considerably within a short time, Patil et. al. (2003). Frequency of natural mutation is very low and hence artificial mutations are induced and genetic variability is best enhanced with the application of mutagens. It is 
essential to restore the lost genetic variability of different varieties from different part of the world through different techniques like induced mutagenesis. Thus, mutation breeding or induced mutation is having great potential for the improvement of traditional agricultural crops like winged bean.

Despite possessing multipurpose utility and immense potential as detailed above the winged bean has remained unfamiliar among society because of the high amount of antinutritional factors, absence of market demands, labour intensive nature of crop and long duration of its life cycle. To overcome these, negative properties, it's an urgent need to develop improved varieties of winged by using the novel approach of mutation breeding.

\section{MATERIALS AND METHODS}

The experimental plant material selected for the present investigation comprised two varieties (cultivars) of winged bean (Psophocarpus tetragonolobus (L.) DC.) namely II-EC-178313 and 2I-EC38825. Germplasm of these two cultivars was procured from National Bureau of Plant Genetic Resources, Regional Station PKV, Akola, (M.S.).

The chemical mutagens viz., Ethyl Methane Sulfonate (EMS) and Sodium Azide (SA), manufactured by Sigma chemical company Ltd., U.S.A. was used in the present investigation. The pilot experiments were conducted for determining the suitable concentrations for further studies.

Prior to mutagenic treatments seeds were immersed in distilled water for 6 hours. The presoaking enhances the rate of uptake of the mutagen through an increase in cell permeability and also initiates metabolism in the seeds for treatment. Such presoaked seeds were later on immersed in the mutagenic solutions for 6 hours with an intermittent shaking. Seeds soaked in distilled water for 12 hours served as control. All the chemical mutagenic treatments were given at room temperature of $25 \pm 2^{\circ} \mathrm{C}$.

The different concentrations used for the chemical treatments were $0.05 \%, 0.10 \%$ and $0.15 \%$ for EMS and $0.01 \%, \quad 0.02 \%$ and $0.03 \%$ for SA respectively. Immediately after the completion of treatment the seeds were washed thoroughly under tap water. Later on, they were kept for post soaking in distilled water for 2 hours.

For each treatment, a batch of 450 presoaked seeds was used. Out of 450 seeds, a lot of 300 seeds from each treatment was sown in field following randomized block design (RBD) with three replications along with control as the $M_{1}$ generation. The seeds were sown at a distance of $30 \mathrm{~cm}$ between the plants and $90 \mathrm{~cm}$ between the rows. The field experiments were carried out at the experimental field of Botany Department, Dr. Babasaheb Ambedkar Marathwada University Aurangabad (M.S.), during kharif season. Further the $\mathrm{M}_{1}$ generation was observed carefully to record plants with different types of chlorophyll deficient sectors in leaves and frequency of such plants was calculated.

\section{RESULTS AND DISCUSSION}

The critical screening of the $\mathrm{M}_{1}$ generation of winged bean revealed the induction of chlorophyll deficient sectors of different types in the leaves at all the concentrations of both the mutagens such sectors were of yellow (xantha), light green (viridis), yellow green (chlorina) and white (albina) types.They were found at the margins of leaflets, at the apex or distributed throughout the leaf lamina. From the results, it is quite clear that the varied concentrations of both the EMS and SA proved effective in inducing the chlorophyll deficient sectorial types in both the varieties of winged bean. The frequency of chlorophyll deficient sectors increased with the increasing concentration of mutagens in both the varieties of winged bean.

The frequency of chlorophyll deficient sectorial plants ranged from $3.53 \%$ to $5.00 \%$ and $3.33 \%$ to $6.03 \%$ after EMS treatments in variety II-EC-178313 and 2I-EC38825 of winged bean respectively. While in case of SA treatments the frequency values ranged from $4.31 \%$ to $5.88 \%$ and $2.58 \%$ to $4.76 \%$ in the pertinent varieties of winged bean (Table - 1and 2).

The mutagen induced chlorophyll deficient sectors embody one of the prime biological effects. This effect however, is restricted to the $M_{1}$ generation only. In recent years, it has been very much appreciated that the in-depth study of such sectors (also described as leaf chlorophyll chimeras) would prove immensely helpful in having a rapid estimation of effectiveness of mutagenic 
agent and new treatment conditions right in $M_{1}$ generation itself.

Stadler (1930) was first to observe that mutations induced by seed irradiation appeared in the form of sectors in $M_{1}$ plants. Anderson et. al. (1949) demonstrated that the analysis of mutated sectors can greatly help in tracing the ontogeny of organs in $\mathrm{M}_{1}$ plants. Motto et.al. (1975) reported chlorophyll chimeras in french bean after EMS treatments. Recently Mahamune and Kothekar (2012) observed chlorophyll chimeras in French bean after EMS and SA treatments. Goud (1967) opined that differential response of the embryonic cells to mutagen causes chimerism. Developments of chlorophyll chimeras in plants become possible when a sector of the multicellular embryo become mutated. The embryo contains different sets of meristematic initials which are potentially capable of producing certain portion of the mature plant. A differential response of such embryonic cells to the mutagen causes chimerism.

Chary (1983) recorded higher frequency of chlorophyll deficient sectors after chemical mutagenic treatments than gamma rays and magnetic field treatments. $\mathrm{He}$ further stated that EMS was the most effective mutagen among all chemical mutagens in producing chlorophyll deficient sectors.

\section{CONCLUSION}

From above study, it is concluded that the different types of chlorophyll deficient sectors such as xantha, viridis, chlorina and albino could be detected in the $M_{1}$ generation of winged bean. The frequency of sectorial plants showed an increasing trend with the increasing concentration of EMS and SA in both the varieties of winged bean.

Table - 1: Effect of EMS on the frequency of plants carrying chlorophyll deficient sectors in $M_{1}$ generation of Psophocarpus tetragonolobus (L.) DC.

\begin{tabular}{|c|c|c|c|}
\hline Variety & Concentration & Frequency of plants carrying chlorophyll deficient sectors (\%) & \pm S.E. \\
\hline \multirow{4}{*}{$\begin{array}{l}\text { II-EC- } \\
178313\end{array}$} & Control & - & - \\
\hline & $0.05 \%$ & 3.53 & 0.33 \\
\hline & $0.10 \%$ & 4.62 & 0.66 \\
\hline & $0.15 \%$ & 5.00 & 0.33 \\
\hline \multirow{4}{*}{$\begin{array}{l}21-E C- \\
38825\end{array}$} & Control & - & - \\
\hline & $0.05 \%$ & 3.33 & 0.33 \\
\hline & $0.10 \%$ & 5.04 & 0.57 \\
\hline & $0.15 \%$ & 6.03 & 0.88 \\
\hline
\end{tabular}

\pm S.E. $=$ Standard Error

Table - 2: Effect of SA on the frequency of plants carrying chlorophyll deficient sectors in $M_{1}$ generation of Psophocarpus tetragonolobus (L.) DC.

\begin{tabular}{|l|l|l|l|}
\hline Variety & Concentration & Frequency of plants carrying chlorophyll deficient sectors (\%) & \pm S.E. \\
\hline \multirow{3}{*}{$\begin{array}{l}\text { II-EC- } \\
178313\end{array}$} & Control & - & - \\
\cline { 2 - 4 } & $0.01 \%$ & 4.31 & 0.66 \\
\cline { 2 - 4 } & $0.02 \%$ & 4.54 & 0.66 \\
\cline { 2 - 4 } & $0.03 \%$ & 5.88 & 0.57 \\
\hline \multirow{2}{*}{$\begin{array}{l}\text { 2I-EC- } \\
38825\end{array}$} & Control & - & - \\
\cline { 2 - 4 } & $0.01 \%$ & 2.58 & 0.33 \\
\cline { 2 - 4 } & $0.02 \%$ & 4.42 & 0.66 \\
\cline { 2 - 5 } & $0.03 \%$ & 4.76 & 0.33 \\
\hline
\end{tabular}

\pm S.E. $=$ Standard Error 


\section{REFERENCES}

Acharya, S. N., Thomas, J. E. and Basu, S. K. (2007): Improvement in the medicinal and nutritional properties of fenugreek (Trigonella foenum graecum L.): In: Acharya, S. N., Thomas, J. E. (eds) Advances in medicinal plant research, Research Signpost, Trivendrum, Kerala, India.

Arenaz, P., Hallberg, L., Mancillas, F., Gutierrez, G. and Garcia, S. (1989): Sodium azide mutagenesis in mammals; Inability of mammalian cells to convert azide to mutagenic intermediate. Mutation Research, 277:63-67.

Anderson, E.G., Longely, A.E., Li C. H. and Rutherford, K. L. (1949): Heredity effects produced in maize by radiation from the bikini atomic bomb: Studies on seedling and pollen of the exposed generation. Genetics. 34:639-646.

Chary, S.N. (1983): Mutagenic studies in pigeon pea (Cajanas cajan L. Millsp.). Ph.D. Thesis, Osmania University, Hyderabad.

Goud, J.V. (1967): Induced mutations in bread wheat. Ind.J. Genet., 27:40-55.

Motto, M., Soressi, G.P. and Salamini (1975): Mutation frequencies and chimeric formation in
Phaseolus vulgaris after EMS treatment of dormant seeds. Radiation Bot.15 (3): 291-299.

Mahamune, S.E. and Kothekar, V.S. (2012): Induced chemical and physical mutagenic studies in $\mathrm{M}_{1}$ generation of French bean (Phaseolus vulgaris L.). Current Botany, 3(3):17-21.

Masefield, G.B. (1973): Psophocarpus tetragonolobus a crop with a future? Field Crop Abstract. 26: 157-160.

National Academy of Sciences (1975): The Winged Bean- A High Protein Crop of the Tropics. Natl. Acad. Sci. Washington. D.C.

Okagaki, R.J., Neffer, M.G. and Wessler, S.R. (1991): A deletion common to two independently derived waxy mutations of maize. Genetics, 127:425-431.

Patil, S., Nair, B., Maheshwari, J.J. and Pillewan, S. (2003): Variability studies in $M_{2}$ and $M_{3}$ generation of soybean mutants. Advances in plant Sciences, 16 (1): 295-299.

Stadler, L.G. (1930): Some genetic effects of X-rays in plants. J. Heredity, 23:3-19.

Verdcourt, B. and Halliday, P. (1978): A revision of Psophocarpus (Leguminosae: Papilliodeae: Phaseoleae). Kew Bull., 32 (2): 191-227.
*Corresponding Author:

A.S.Sonavane

Email: ajinathsonavane@gmail.com 